\title{
Sources of shared variability in muscle and bone weight distribution and estimation of carcass meatiness and bone utilizing orthogonal carcass traits derived from factor analysis in Japanese quail
}

\author{
KA Shahin * \\ Department of Animal Production, Faculty of Agriculture, Ain Shams University, PO Box 68, \\ Hadayek Shoubra, 11241 Cairo, Egypt
}

(Received 6 November 1995; accepted 17 September 1996)

\begin{abstract}
Summary - A factor analysis with a varimax rotation was applied to 10 highly intercorrelated meatiness and bone traits in 110 Japanese quail to disclose the main sources of shared variability, to deduce the factors that control muscle and bone distribution and to predict total carcass muscle and bone content from orthogonal carcass traits. Most of the common variability (88.2\%) in muscle and bone weight distribution could be accounted for by factors representing, in a decreasing order of contribution in total variance: meatiness; limb bones (skeletal support system); neck; and breast bone. The correlation coefficient between the meatiness rotated factor and carcass muscle was 0.91 and that between the skeletal support factor and total carcass bone was 0.75 . The rotated factors derived from quail in the present study and from Pekin duckling in a previous study (Shahin, 1996a, Ann Zootech 45, 173-184) were compared. It is shown that common factors control meatiness and bone development in both species.
\end{abstract}

muscle weight variations / bone weight variations / muticollinearity / factor analysis / Japanese quail

Résumé - Origines de la variabilité conjointe de la distribution corporelle du muscle et du squelette et de leur estimation en utilisant les variables orthogonales dérivées d'une analyse factorielle chez la caille japonaise. Une analyse factorielle utilisant une rotation varimax a été appliquée à dix caractéristiques de muscles et d'os sur 110 cailles Japonaises afin de : i) identifier les principales sources de variabilité commune, ii) déterminer les facteurs contrôlant la répartition des muscles et des os de la carcasse, iii) prédire la quantité totale de muscles et d'os dans la carcasse à partir des caractéristiques de la carcasse orthogonale. L'essentiel de la variabilité $(88,2 \%)$ de la répar-

\footnotetext{
* Correspondence and reprints
} 
tition pondérale des muscles et des os pourrait être attribué à quatre facteurs : les muscles (I), les os des membres (II), le cou (III) et les os pectoraux (IV). Le coefficient de corrélation entre le facteur I de la rotation varimax et les muscles de la carcasse était de 0,91 ; celui du facteur II et des os de la carcasse de 0,75 . Les facteurs de la rotation varimax déterminés pour les cailles, dans la présente étude, et pour les canards Pékin, dans une étude précédente (Shahin, 1996a), ont été comparés. Il est montré que des facteurs communs contrôlent le développement des muscles et des os dans les deux espèces.

répartition pondérale / muscle / os / analyse factorielle / caille japonaise

\section{INTRODUCTION}

Independent factor scores derived from the factor analysis technique have been used advantageously as predictors of total carcass muscle and bone and other live performance traits and as a selection criterion for genetic improvement of muscle weight distribution (Cook, 1966; Ricard, 1980; Shahin et al, 1993; Shahin, 1996a,b).

The objective of this study on Japanese quail was to evaluate the relationships involving the weight of muscle and bone in various carcass cuts, with the weight of the corresponding tissue in the carcass by applying the factor analysis method and simple and multiple regressions. The main sources of shared variability and the factors that control muscle and bone distribution were also studied.

\section{MATERIALS AND METHODS}

\section{Source of data}

One-hundred-and-ten (56 males and 54 females) Japanese quail (Coturnix coturnix japonica), the progeny of 33 sires raised at the Faculty of Agriculture, Tanta University, Egypt, were used in this study. A growth diet containing $24 \%$ protein with a metabolizable energy of $2931 \mathrm{kcal} / \mathrm{kg}$ from hatching to 6 weeks of age was used. Feed and water were provided ad libitum and conventional brooding and rearing practices were followed.

\section{Traits considered}

At 6 weeks, the birds were killed and the head was removed at the atlanto-occipital articulation. The right side of the carcass was jointed into the following commercial cuts: thigh, drumstick, wing, breast and neck. In each cut, fat (skin plus subcutaneous and intermuscular fat), muscle and bone were dissected and weighed. The sum of the weights of these parts over all the cuts gave the weight of the total side muscle, bone and fat. The data from males and females were combined as their dispersion matrices did not prove to differ significantly.

\section{Statistical analysis}

The original (non-independent) variables were initially described in terms of means, phenotypic variation and intercorrelations. The data were then subjected to the factor analysis procedure (SAS, 1988) where the main source of shared variation among correlated muscling and bone variables $(P)$ was expressed in terms of fewer mutually uncorrelated common factors (latent variables) $\mathrm{F}_{1}, \ldots, \mathrm{F}_{\mathrm{q}}$ (where $q<p$ ) than the original variables (Darton, 1980).

The model used was as follows:

$$
\mathrm{X}=\Lambda F+\mathrm{U}
$$

where: $\mathrm{X}$, a $p \times I$ vector of observable variables; $\Lambda$, a $p \times q$ matrix of factor loading 'factor- variate correlations'; 
$F$, a $q \times I$ vector of factors and; $U$, a $p \times I$ vector of specific 'unique' factors.

A built-up step-wise multiple regression was used to evaluate the relative contribution of the original meatiness and bone variables and their varimax rotated factors to total side muscle weight (TSM) and total side bone weight (TSB).

\section{RESULTS AND DISCUSSION}

\section{Original 'non-independent' variables}

The muscle and bone weights relative to body weight were estimated at $39.7 \%$ and $9.6 \%$ respectively in Japanese quail (table I) and $27.9 \%$ and $11.8 \%$ in Pekin ducklings

Table I. Means, standard deviations (SD), coefficient of variability (CV\%) and minimum and maximum values for live and carcass traits.

\begin{tabular}{|c|c|c|c|c|}
\hline & Mean & $S D$ & $\mathrm{CV} \%$ & Range \\
\hline Live weight $(\mathrm{g})$ & 123.94 & 22.59 & 18.23 & $80-170$ \\
\hline Total carcass muscle $(\mathrm{g})$ & 49.62 & 11.90 & 23.98 & $24.1-79.2$ \\
\hline Total carcass bone $(\mathrm{g})$ & 11.70 & 1.71 & 14.62 & $8.2-15.8$ \\
\hline Total carcass fat $(\mathrm{g})$ & 7.00 & 1.92 & 27.43 & $3.2-13.2$ \\
\hline \multicolumn{5}{|l|}{ Percentage of live weight } \\
\hline Total muscle & 39.71 & 3.51 & 8.84 & $29.5-48.1$ \\
\hline Total bone & 9.62 & 1.57 & 16.32 & $7.1-14.8$ \\
\hline Total fat & 5.61 & 0.94 & 16.76 & $3.6-8.8$ \\
\hline \multicolumn{5}{|c|}{ Percentage of carcass weight } \\
\hline Total muscle & 72.22 & 3.06 & 4.24 & $61.6-77.9$ \\
\hline Total bone & 17.57 & 2.89 & 16.45 & $12.6-28.0$ \\
\hline Total fat & 10.21 & 1.60 & 15.67 & $7.2-15.6$ \\
\hline \multicolumn{5}{|l|}{ Percentage of total muscle } \\
\hline Drumstick muscle & 10.80 & 1.02 & 9.44 & $8.2-14.6$ \\
\hline Thigh muscle & 22.92 & 1.68 & 7.33 & $19.5-26.9$ \\
\hline Breast muscle & 47.20 & 2.64 & 5.59 & $41.2-53.6$ \\
\hline Wing muscle & 10.64 & 1.32 & 12.41 & $7.3-14.9$ \\
\hline Neck muscle & 3.81 & 0.67 & 17.59 & $2.3-5.8$ \\
\hline Leg muscle & 33.72 & 2.18 & 6.47 & $28.2-38.7$ \\
\hline \multicolumn{5}{|l|}{ Percentage of total bone } \\
\hline Drumstick bone & 13.09 & 1.12 & 8.56 & $10.2-16.2$ \\
\hline Thigh bone & 26.30 & 2.11 & 8.02 & $20.7-31.4$ \\
\hline Breast bone & 19.53 & 2.82 & 14.44 & $13.2-26.8$ \\
\hline Wing bone & 19.05 & 1.47 & 7.72 & $13.9-23.1$ \\
\hline Neck bone & 10.15 & 1.21 & 11.92 & $7.4-13.5$ \\
\hline Leg bone & 39.39 & 2.55 & 6.47 & $33.9-47.1$ \\
\hline \multicolumn{5}{|l|}{ Muscle: bone ratio } \\
\hline Drumstick & 3.50 & 0.67 & 19.14 & $1.8-5.6$ \\
\hline Thigh & 3.71 & 0.74 & 19.95 & $2.0-5.1$ \\
\hline Breast & 10.43 & 2.43 & 23.30 & $5.8-16.2$ \\
\hline Wing & 2.37 & 0.50 & 21.10 & $1.2-3.7$ \\
\hline Neck & 1.58 & 0.31 & 19.62 & $0.9-2.3$ \\
\hline Whole carcass & 4.23 & 0.75 & 17.73 & $2.2-6.1$ \\
\hline
\end{tabular}


(Shahin, 1996a). There was a much higher TSM:TSB ratio in the quail.

The variability of muscle in the limbs appears to be higher than in the breast in Japanese quail (table I) and lower in Pekin ducklings (Shahin, 1996a). The variability of the muscle was comparable to that for bone in the leg, but was much lower in the breast.

\section{The relationship with TSM and TSB}

The weight of muscle or bone in the individual cuts appeared to be highly correlated with the total weight of the corresponding tissue in the carcass (table II).

The separable muscle in the thigh was associated with $90 \%$ of the variation in TSM in quail (table II) and 72\% in Pekin ducklings (Shahin, 1996a). Breast muscle weight alone accounted for $96.6 \%$ of the variability in TSM in Japanese quail (table III) and $89 \%$ in Pekin ducklings (Shahin, 1996a). Slight improvements in the accuracy of the TSM estimates in quail (table III) appeared with a stepwise addition of the weight of muscle occurring in thigh, wing and drumstick.

For TSB 76\% of the variability was explained by thigh bone in quail (table IV) and $65 \%$ by wing bone in Pekin ducklings (Shahin, 1996a). The improvement in the accuracy of the TSB estimates in quail (table IV) was more obvious with stepwise inclusion of the weight of the bone found in the breast, wing, drumstick and neck.

\section{Varimax rotated 'independent' factors}

\section{Their interpretation}

The principal initial factors and the final varimax solutions are presented in table $\mathrm{V}$. Four common factors (one for meatiness and the others for skeletal structures) have been identified, which contribute $88 \%$ of the variability of the 10 original variables, leaving $12 \%$ to the 10 'special' factors.

The first factor ('meatiness': I) is characterized by high positive loadings on meatiness traits (table V; Rouvier and Ricard,1967; Ricard, 1980; Shahin, 1996a). The variables that are associated with drumstick muscle and thigh muscle have the highest loadings, followed by the breast and wing muscle. This factor accounted for $63 \%$ of the variation of the original variables in quail (table V) and 54\% in Pekin ducklings (Shahin, 1996a). Compared with ducks, quails seemed to vary more in meatiness and less in skeletal structure (table V; Shahin, 1996a).

The second factor ('skeletal support system': II), giving relatively high weight to limb bones, accounted for an additional $14.7 \%$ of the total variation. The variables associated with drumstick bone and thigh bone had the highest loadings followed by those associated with wing bone. In White Leghorn fowls the leg and wing measurements are affected by a common factor which was independent of that of the head (Wright, 1954).

The third factor ('neck factor': III) accounted for $5.5 \%$ of the total variation with high loadings on the neck muscle and bone. The neck structures enable the bird to maintain its balance by shifting the center of gravity during running and flying. A neck factor explaining $8.8 \%$ of the total variation in meatiness and bone traits was also identified in Pekin ducklings (Shahin, 1996a).

Species differences seemed to exist in relation to the fourth factor (breast bone: IV) which acted on breast bone in quail and on drumstick bone 'tibia' in Pekin ducklings (Shahin, 1996a). The way the weight is distributed over the body and genetic adaptations to physiological needs might be reasons for the difference in this factor (Goss, 1981). 


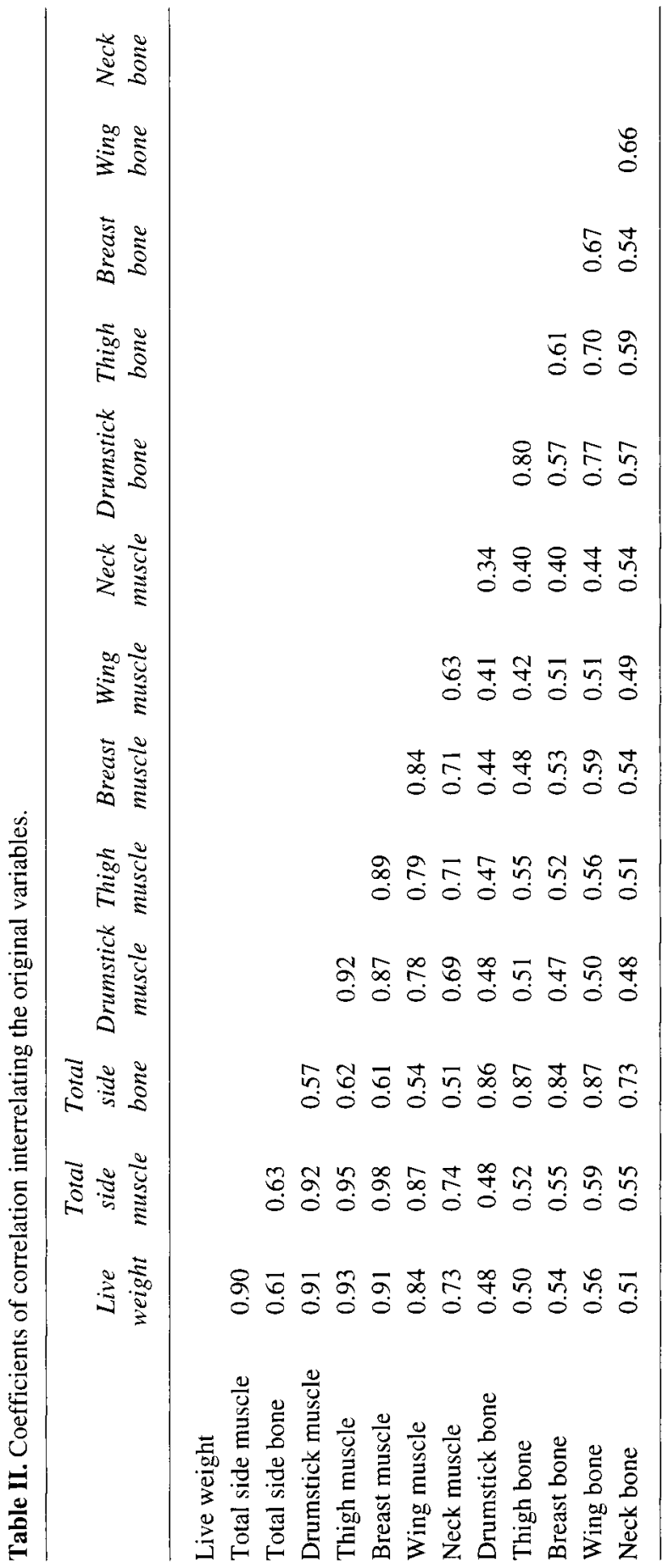


Table III. Step-wise multiple regression of total side muscle weight (g) on original muscle traits and on orthogonal factor scores.

\begin{tabular}{|c|c|c|c|c|c|c|}
\hline Step & $\begin{array}{l}\text { Independent variables } \\
\text { (predictors) }\end{array}$ & Intercept & $\begin{array}{c}\text { Regression } \\
\text { coefficient } \\
b\end{array}$ & $S E$ & $R^{2}$ & $\begin{array}{l}\text { Residual } \\
\text { standard } \\
\text { deviation }\end{array}$ \\
\hline \multicolumn{7}{|c|}{ (I) Original muscle traits as independent variables } \\
\hline 1 & Breast muscle & 3.18 & 1.84 & 0.03 & 0.966 & 1.13 \\
\hline 2 & $\begin{array}{l}\text { Breast muscle } \\
\text { Thigh muscle }\end{array}$ & 1.64 & $\begin{array}{l}1.24 \\
1.51\end{array}$ & $\begin{array}{l}0.04 \\
0.08\end{array}$ & 0.992 & 0.56 \\
\hline 3 & $\begin{array}{l}\text { Breast muscle } \\
\text { Thigh muscle } \\
\text { Wing muscle }\end{array}$ & 1.06 & $\begin{array}{l}1.11 \\
1.40 \\
1.04\end{array}$ & $\begin{array}{l}0.03 \\
0.06 \\
0.12\end{array}$ & 0.995 & 0.43 \\
\hline 4 & $\begin{array}{l}\text { Breast muscle } \\
\text { Thigh muscle } \\
\text { Wing muscle } \\
\text { Drumstick muscle }\end{array}$ & 0.50 & $\begin{array}{l}1.06 \\
1.09 \\
0.96 \\
1.17\end{array}$ & $\begin{array}{l}0.03 \\
0.06 \\
0.09 \\
0.14\end{array}$ & 0.997 & 0.34 \\
\hline 5 & $\begin{array}{l}\text { Breast muscle } \\
\text { Thigh muscle } \\
\text { Wing muscle } \\
\text { Drumstick muscle } \\
\text { Neck muscle }\end{array}$ & 0.30 & $\begin{array}{l}1.05 \\
1.06 \\
0.95 \\
1.14 \\
0.70\end{array}$ & $\begin{array}{l}0.03 \\
0.06 \\
0.09 \\
0.14 \\
0.22\end{array}$ & 0.997 & 0.32 \\
\hline \multicolumn{7}{|c|}{ (II) Orthogonal factor scores as independent variables } \\
\hline 1 & $\mathrm{FC} 1$ & 24.89 & 5.51 & 0.24 & 0.830 & 2.52 \\
\hline 2 & $\begin{array}{l}\mathrm{FC} 1 \\
\mathrm{FC} 2\end{array}$ & 24.89 & $\begin{array}{l}5.51 \\
1.58\end{array}$ & $\begin{array}{l}0.19 \\
0.19\end{array}$ & 0.897 & 1.96 \\
\hline 3 & $\begin{array}{l}\text { FC1 } \\
\text { FC2 } \\
\text { FC4 }\end{array}$ & 24.89 & $\begin{array}{l}5.51 \\
1.58 \\
1.25\end{array}$ & $\begin{array}{l}0.15 \\
0.15 \\
0.15\end{array}$ & 0.939 & 1.52 \\
\hline 4 & $\begin{array}{l}\mathrm{FC} 1 \\
\mathrm{FC} 2 \\
\mathrm{FC} 4 \\
\mathrm{FC} 3\end{array}$ & 24.89 & $\begin{array}{l}5.51 \\
1.58 \\
1.25 \\
1.17\end{array}$ & $\begin{array}{l}0.09 \\
0.09 \\
0.09 \\
0.09\end{array}$ & 0.976 & 0.95 \\
\hline
\end{tabular}

Table VI shows the coefficients of congruence between the Japanese quail of the present study and the Pekin ducklings of Shahin (1996a) for the four varimax rotated factors. Factors I and III controlled the same traits in Japanese quails and Pekin ducklings. However, factor II, which acted on all bones of the extremities in Japanese quails, matched factor IV for the ducks very well. This factor acted specifically on the drumstick bone in Pekin ducklings. Factor IV which controls breast bone development in Japanese quails corresponded to factor II in Pekin ducklings. It appeared that the muscle and bone weight distribution in both species were largely controlled by the same orthogonal factors. 
Table IV. Step-wise multiple regression of total side bone weight $(\mathrm{g})$ on original bone traits and on orthogonal factor scores.

\begin{tabular}{|c|c|c|c|c|c|c|}
\hline Step & $\begin{array}{l}\text { Independent variables } \\
\text { (predictors) }\end{array}$ & Intercept & $\begin{array}{c}\text { Regression } \\
\text { coefficient } \\
b\end{array}$ & $S E$ & $R^{2}$ & $\begin{array}{l}\text { Residual } \\
\text { standard } \\
\text { deviation }\end{array}$ \\
\hline \multicolumn{7}{|c|}{ (I) Original bone traits as independent variables } \\
\hline 1 & Thigh bone & 1.35 & 2.93 & 0.16 & 0.762 & 0.42 \\
\hline 2 & $\begin{array}{l}\text { Thigh bone } \\
\text { Breast bone }\end{array}$ & 1.15 & $\begin{array}{l}1.94 \\
1.49\end{array}$ & $\begin{array}{l}0.12 \\
0.11\end{array}$ & 0.911 & 0.26 \\
\hline 3 & $\begin{array}{l}\text { Thigh bone } \\
\text { Breast bone } \\
\text { Wing bone }\end{array}$ & 0.39 & $\begin{array}{l}1.41 \\
1.09 \\
1.83\end{array}$ & $\begin{array}{l}0.09 \\
0.08 \\
0.16\end{array}$ & 0.960 & 0.17 \\
\hline 4 & $\begin{array}{l}\text { Thigh bone } \\
\text { Breast bone } \\
\text { Wing bone } \\
\text { Drumstick bone }\end{array}$ & 0.38 & $\begin{array}{l}1.06 \\
1.11 \\
1.36 \\
1.37\end{array}$ & $\begin{array}{l}0.10 \\
0.07 \\
0.16 \\
0.22\end{array}$ & 0.971 & 0.15 \\
\hline 5 & $\begin{array}{l}\text { Thigh bone } \\
\text { Breast bone } \\
\text { Wing bone } \\
\text { Drumstick bone } \\
\text { Neck bone }\end{array}$ & 0.28 & $\begin{array}{l}0.97 \\
1.06 \\
1.06 \\
1.36 \\
1.08\end{array}$ & $\begin{array}{l}0.08 \\
0.06 \\
0.14 \\
0.18 \\
0.16\end{array}$ & 0.980 & 0.12 \\
\hline \multicolumn{7}{|c|}{ (II) Orthogonal factor scores as independent variables } \\
\hline 1 & $\mathrm{FC} 2$ & 5.87 & 0.64 & 0.05 & 0.563 & 0.56 \\
\hline 2 & $\begin{array}{l}\mathrm{FC} 2 \\
\mathrm{FC} 4\end{array}$ & 5.87 & $\begin{array}{l}0.64 \\
0.39\end{array}$ & $\begin{array}{l}0.04 \\
0.04\end{array}$ & 0.778 & 0.40 \\
\hline 3 & $\begin{array}{l}\mathrm{FC} 2 \\
\mathrm{FC} 4 \\
\mathrm{FCl}\end{array}$ & 5.87 & $\begin{array}{l}0.64 \\
0.39 \\
0.27\end{array}$ & $\begin{array}{l}0.03 \\
0.03 \\
0.03\end{array}$ & 0.878 & 0.30 \\
\hline 4 & $\begin{array}{l}\text { FC2 } \\
\text { FC4 } \\
\text { FC1 } \\
\text { FC2 }\end{array}$ & 5.87 & $\begin{array}{l}0.64 \\
0.39 \\
0.27 \\
0.26\end{array}$ & $\begin{array}{l}0.01 \\
0.01 \\
0.01 \\
0.01\end{array}$ & 0.970 & 0.14 \\
\hline
\end{tabular}

\section{Shared variability}

The results (table $\mathrm{V}$ ) indicated that about $81 \%$ to $94 \%$ of the variation in meatiness and bone traits were brought about by the common factors, whereas $6 \%$ to $19 \%$ of their variation were contributed by unique factors specific for each trait. The relatively high estimates of common variance for meatiness traits indicated that improving any one of them could result in the simultaneous improvement in the remaining muscling traits.

In terms of highest communalities (table V and Shahin (1996a)) the values 
Table V. Explained variation associated with unrotated and rotated factor analysis along with communalities and unique factor for each variable. Correlations between factor score coefficients and original variables.

\begin{tabular}{|c|c|c|c|c|c|c|c|c|c|c|}
\hline & \multicolumn{4}{|c|}{ Unrotated common factors } & \multicolumn{4}{|c|}{ Rotated common factors } & \multirow[b]{2}{*}{ Communalities } & \multirow{2}{*}{$\begin{array}{l}\text { Unique } \\
\text { factor }\end{array}$} \\
\hline & $I$ & II & III & $I V$ & $I$ & II & III & $I V$ & & \\
\hline Drumstick muscle & 0.856 & -0.370 & -0.185 & -0.121 & 0.901 & 0.302 & 0.102 & 0.068 & 0.918 & 0.082 \\
\hline Thigh muscle & 0.885 & -0.339 & -0.147 & -0.052 & 0.889 & 0.301 & 0.142 & 0.147 & 0.923 & 0.077 \\
\hline Breast muscle & 0.883 & -0.352 & -0.056 & 0.048 & 0.872 & 0.225 & 0.213 & 0.231 & 0.910 & 0.090 \\
\hline Wing muscle & 0.815 & -0.361 & -0.078 & 0.145 & 0.828 & 0.152 & 0.158 & 0.297 & 0.822 & 0.178 \\
\hline Neck muscle & 0.745 & -0.252 & 0.358 & -0.138 & 0.698 & 0.101 & 0.573 & 0.007 & 0.826 & 0.174 \\
\hline Drumstick bone & 0.726 & 0.540 & -0.178 & -0.231 & 0.205 & 0.903 & 0.147 & 0.161 & 0.905 & 0.095 \\
\hline Thigh bone & 0.751 & 0.468 & -0.168 & -0.217 & 0.268 & 0.858 & 0.158 & 0.163 & 0.859 & 0.141 \\
\hline Breast bone & 0.725 & 0.305 & -0.042 & 0.567 & 0.284 & 0.390 & 0.168 & 0.825 & 0.942 & 0.058 \\
\hline Wing bone & 0.797 & 0.417 & 0.025 & 0.052 & 0.277 & 0.686 & 0.319 & 0.405 & 0.813 & 0.187 \\
\hline Neck bone & 0.738 & .252 & 0.542 & -0.039 & 0.244 & 0.423 & 0.778 & 0.245 & 0.904 & 0.096 \\
\hline$\%$ of variance & 63.1 & 14.7 & 5.5 & 4.9 & & & & & & \\
\hline Description & & & & & $\begin{array}{c}\text { Meati- } \\
\text { ness }\end{array}$ & $\begin{array}{l}\text { Limb } \\
\text { bones }\end{array}$ & Neck & $\begin{array}{c}\text { Breast } \\
\text { bone }\end{array}$ & & \\
\hline
\end{tabular}

Table VI. Coefficients of congruence between varimax factors of muscle and bone variation in Japanese quail and Pekin ducklings ${ }^{1}$.

\begin{tabular}{lcccr}
\hline $\begin{array}{l}\text { Factors for } \\
\text { Japanese } \\
\text { quail }\end{array}$ & \multicolumn{4}{c}{ Factors for Pekin ducklings } \\
\cline { 2 - 5 } & $I$ & $I I$ & \multicolumn{1}{c}{ III } & \multicolumn{1}{c}{$I V$} \\
\hline I & 0.8972 & -0.3839 & -0.2874 & -0.4522 \\
II & -0.6146 & 0.2668 & -0.1556 & 0.8021 \\
III & -0.5863 & -0.2415 & 0.8838 & -0.2822 \\
IV & -0.1350 & 0.7659 & -0.1776 & -0.3187
\end{tabular}

${ }^{1}$ Shahin, 1996a.

were higher in quail than in duck (thigh muscle: $92.3 \%$ vs $82.4 \%$; breast bone: 94.2 vs $84.5 \%$ ). This indicated that the musculature of the thigh and the skeletal development of the breast could reflect other meat and bone characteristics in the quail than in the duck. Wing muscle and bone had the lowest communality with the greatest uniqueness of their own (table V). About $81-82 \%$ of the variation in wing muscle and bone was controlled by common factors, whereas $18-19 \%$ of their variation was contributed by the unique factor specific for either the wing muscle or wing bone. 


\section{Their relationship with TSM and TSB}

The meatiness factor score (FC1) alone accounted for $83 \%$ of the variation in total side muscle weight in Japanese quail (table III), and $81 \%$ in Pekin ducklings (Shahin, 1996a). Results of the stepwise multiple regression of the total side muscle weight on the four varimax factor scores showed that $R^{2}$ increased from 0.90 to 0.94 to 0.98 and RSD of the estimate decreased from 1.96 to 1.52 to $0.95 \mathrm{~g}$ as FC2, FC4 and FC3 orthogonal factor scores were added in step-wise.

The limb bones factor score (FC2) alone accounted for $56 \%$ of the variation in total side bone weight (table IV). $\mathrm{R}^{2}$ increased from 0.78 to 0.88 to 0.97 and the RSD of the estimate decreased from 0.40 to 0.30 to $0.14 \mathrm{~g}$ with the step-wise inclusion of FC4, $\mathrm{FC} 1$ and $\mathrm{FC} 3$ orthogonal factor scores.

\section{CONCLUSION}

The results of this study on Japanese quail confirmed those found with Pekin ducklings (Shahin, 1996a), demonstrating the advantages of the factor analysis technique versus the multiple regression technique for consolidating several intercorrelated meatiness and bone traits into a few interpretable independent factors. These then help to clarify the relationship of the weight of muscle and bone in the various cuts with the total weight of the corresponding tissue in the carcass. Also, factor analysis helped to show that the structural tissues of the body (muscular and skeletal 'bone') in quail and ducks were largely controlled by the same orthogonal factors.

\section{REFERENCES}

Cook AG (1966) Genetical aspects of growth and form in animals. $Q$ Rev Biol 41, 131-190

Darton RA (1980). Rotation in factor analysis. The Statistician 29, 167-194

Goss RJ (1981) Physiological adaptations of growth. Comp Animal Nutrition 4, 1-32

Ricard FH (1980) Carcass conformation of poultry and game birds. In: Meat Quality in Poultry and Game Birds (Mead GC, Freeman F, eds) British Poultry Science Ltd, Edinburgh, 31-50

Rouvier R, Ricard FH (1967) Study of the anatomical composition of chicken. II. Variability of the distribution of meat and bone in Bresse-Pile cockerels. Ann Zootech 16, 357-374

SAS (1988) SAS User's Guide. Statistical Analysis System Institute Inc, Cary, NC

Shahin KA (1996a) Analysis of muscle and bone weight variations in an Egyptian strain of Pekin ducklings. Ann Zootech 45, 173-184

Shahin KA (1996b) Selection indexes using live measurements or their varimax rotated factors for improving meat weight distribution-Application on carcasses of Pekin ducks. Arch Geflugelkunde 60, 103-108

Shahin KA, Soliman AM, Moukhtar AE (1993) Sources of shared variability for the Egyptian buffalo body shape (conformation). Livestock Prod Sci 36, 323-334

Wright $S$ (1954) The interpretation of multivariate systems. Chapter 2. In: Statistics and Mathematics in Biology (Kempthorn O, Bancroft TA, Gowen JW, Lush JL, eds) The Iowa State College Press, Ames, Iowa, 11-33 